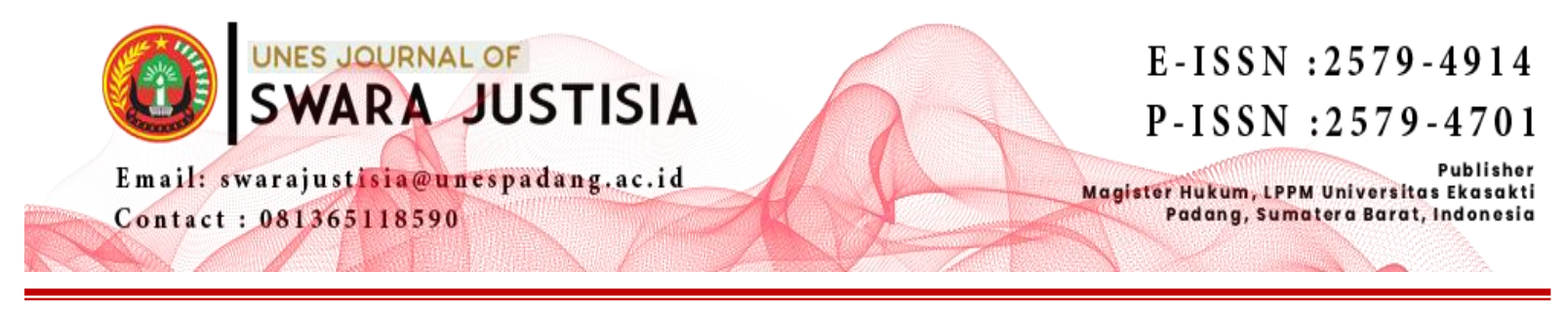

\title{
PENERAPAN SANKSI BAGI PELAKU USAHA YANG MENGEDARKAN PRODUK PANGAN TANPA LABEL HALAL PADA KEMASAN DI KOTA PADANG
}

\author{
${ }^{1}$ Widya Sari, ${ }^{2}$ Iyah Faniyah \\ ${ }^{1}$ Program Magister Ilmu Hukum,Universitas Ekasakti, Padang \\ Email: wdy.15@gmail.com \\ ${ }^{2}$ Program Magister Ilmu Hukum,Universitas Ekasakti, Padang \\ Email: iyahfaniyah01@gmail.com
}

\begin{abstract}
The Halal label is one of the most important things to include on the packaging. The label is useful to find out whether the products produced by the manufacturer are halal so that they are safe for consumption by consumers, especially Muslim consumers in Indonesia. According to Article 87 paragraph 3 letter e of Law Number 18 of 2012 which states that the inclusion of labels on food packaging must contain information regarding halal for those who are required. Based on the article, it is known that the halal label is one of the information included on the packaging. But the fact is that until now there are still many manufacturers who produce their products that do not include a halal label on the packaging.
\end{abstract}

Keywords: Business Actor, Packaged Food, Halal Label

\begin{abstract}
ABSTRAK
Label Halal merupakan salah satu hal yang sangat penting dicantumkan pada kemasan. label tersebut berguna untuk mengetahui apakah produk yang dihasilkan oleh produsen tersebut benar kehalalannya agar aman dikonsumsi oleh konsumen khususnya konsumen Muslim di Indonesia. Menurut Pasal 87 ayat 3 huruf e Undang-undang Nomor 18 Tahun 2012 yang menyebutkan bahwa pencantuman label pada kemasan pangan harus memuat keterangan mengenai halal bagi yang dipersyaratkan. Berdasarkan pasal tersebut maka diketahui bahwa label halal merupakan salah satu informasi yang dicantumkan pada kemasan. Namun faktanya hingga saat ini masih banyak produsen yang memproduksi produknya tidak mencantumkan label halal pada kemasan.
\end{abstract}

Kata Kunci: Pelaku Usaha, Pangan Kemasan, Label Halal

\section{PENDAHULUAN}

Makanan adalah kebutuhan utama untuk keberlangsungan kehidupan. Saat ini, produk makanan baik berupa bahan mentah maupun siap saji (instant), telah beredar luas di pasaran. Beredarnya produk makanan ini memerlukan kontrol yang kuat dari pemerintah maupun 
pihak terkait untuk memastikan bahwa produk makanan yang beredar di pasaran memenuhi standart dan layak untuk dikonsumsi.

Makanan yang sehat adalah makanan yang mempunyai kandungan yang baik bagi manusia. Oleh karena itu sangat penting untuk memperhatikan kondisi suatu makanan. Mengkonsumsi makanan yang baik dan memenuhi standar kesehatan sangat penting demi mencegah terjadinya berbagai kerugian yang akan terjadi karena makanan memiliki pengaruh yang besar terhadap kesehatan. ${ }^{1}$

Pangan termasuk kebutuhan dasar yang sangat esensial dalam kehidupan manusia yang sepenuhnya menjadi hak asasi dari rakyat Indonesia. Pangan berkaitan dengan upaya manusia mempertahankan kelangsungan hidupnya, menjaga kesehatan serta berguna untuk mendapatkan energi yang cukup untuk dapat bekerja secara produktif sehingga tanpa pangan manusia tidak akan dapat menjalankan kegiatan sehari-harinya bahkan tidak mungkin dapat untuk bertahan hidup. Menurut Pasal 1 Angka 1 Undang-undang Nomor 18 Tahun 2012 tentang Pangan, yang dimaksud dengan pangan adalah sebagai berikut:

"Segala sesuatu yang berasal dari sumber hayati produk pertanian, perkebunan, kehutanan, perikanan, peternakan, perairan, dan air, baik yang diolah maupun tidak diolah yang diperuntukkan sebagai makanan atau minuman bagi konsumsi manusia, termasuk bahan tambahan Pangan, bahan baku Pangan, dan bahan lainnya yang digunakan dalam proses penyiapan, pengolahan, dan/atau pembuatan makanan atau minuman".

Setiap produk yang diperkenalkan kepada konsumen harus disertai informasi yang benar. Informasi ini diperlukan agar konsumen tidak mempunyai gambaran yang keliru atas produk pangan. Informasi ini dapat disampaikan dengan berbagai cara, salah satunya dengan mencantumkan label pada kemasan pangan. Informasi pada label kemasan produk pangan sangat diperlukan bagi masyarakat agar masing-masing individu secara tepat dapat menentukan pilihan sebelum membeli dan mengkonsumsi produk pangan tersebut.

Bagi orang Islam, pangan juga harus memenuhi syarat halal dan thoyyiban sebagaimana ketentuan yang banyak terdapat dalam kitab suci Al-Qur'an, salah satunya yang terdapat dalam Surat Al-Maidah ayat 88 yang artinya :

"Dan makanlah makanan yang halal lagi baik dari apa yang Allah telah rejekikan kepadamu, dan bertakwalah kepada Allah yang kamu beriman kepadanya".

Ayat dalam Al-Qur'an tersebut memerintahkan kepada manusia untuk memakan makanan yang halal dan baik, dua hal yang merupakan kesatuan dimana halal menurut syariah dan baik menurut segi kesehatan, gizi dan lainnya.

Untuk mengetahui kehalalan dan kesesuaian suatu barang, diperlukan suatu kajian khusus yang membutuhkan pengetahuan multidisiplin, seperti pengetahuan di bidang pangan, kimia, bikomia, teknik industri, biologi, farmasi dan pemahaman tentang syariat. Realitanya banyak produk yang beredar di masyarakat belum semua terjamin kehalalannya meskipun pelaku usaha menyatakan produk barang dipasarkan dinyatakan halal.

Label akan memberikan pengaruh yang sangat besar bagi masyarakat dalam menentukan persepsi halal. Melalui label, masyarakat dapat memperoleh keterangan tentang

\footnotetext{
${ }^{1}$ Abdul Basith Muhammad as-sayyid, Pola Makan Rasulullah, PT. Niaga Swadaya, Yogyakarta, 2009, hlm 19
} 
makanan dan minuman yang bersangkutan sehingga tidak akan terjebak pada hal-hal yang menyesatkan. Selain label keamanan pangan merupakan salah satu faktor penting yang harus diperhatikan dalam konsumsi sehari-hari yang menjadi tanggung jawab dari pelaku usaha atau produsen itu sendiri.

Saat ini permasalahan ketidakjelasan status kehalalan produk pangan kemasan masih menjadi persoalan serius di Indonesia saat ini. Karena kehalalan suatu produk menjadi tolak ukur masyarakat sebagai konsumen untuk membeli suatu barang yang akan dibelinya. Suatu produk yang akan dijual atau diedarkan kepada konsumen harus mengikuti standar yang sudah ditetapkan oleh pemerintah, baik menurut undang-undang ataupun peraturan perundang-undangan lainnya, akan tetapi pelaku usaha dalam memperdagangkan suatu produk pangannya sering melakukan berbagai cara agar produk pangan yang dijualnya tersebut laku dalam jumlah yang banyak meskipun terkadang menghalalkan berbagai cara agar konsumen tertarik untuk membelinya.

Dalam UUPK Pasal 8 ayat (1) huruf $\mathrm{h}$ mengatur bahwa pelaku usaha dilarang memproduksi atau memperdagangkan barang yang tidak mengikuti ketentuan berproduksi secara halal. Selain itu dalam Undang-undang Nomor 33 Tahun 2014 tentang Jaminan Produk Halal (selajutnya disebut UU JPH) Pasal 4 mengatur bahwa setiap produk makanan yang beredar, dan diperdagangkan di wilayah Indonesia wajib bersertifikasi halal.

Menurut Peraturan Pemerintah Nomor 80 Tahun 2017 tentang Badan Pengawas Obat dan Makanan pada Pasal 4, menjelaskan bahwa dalam melaksanakan tugas pengawasan Obat dan Makanan, BPOM mempunyai kewenangan menerbitkan izin edar produk dan sertifikasi sesuai dengan standar, dan persyaratan keamanan, khasiat/mandaat dan mutu, serta pengujian obat dan makanan, melakukan intelijen dan penyidikan di bidang pengawasan obat dan makanan serta pemberian sanksi administratif sesuai dengan ketentuan peraturan perundangundangan. Menurut Pasal 87 UU Pangan menyatakan sebagai berikut :

(1) Setiap orang yang memproduksi pangan di dalam negeri untuk diperdagangkan wajib mencantumkan di dalam dan/atau pada kemasan pangan.

(2) Setiap orang yang mengimpor pangan untuk diperdagangkan wajib mencantumkan label di dalam dan/atau pada kemasan pangan pada saat memasuki wilayah Negara Kesatuan Republik Indonesia.

(3) Pencantuman Label di dalam dan/atau pada kemasan pangan sebagaimana dimaksud pada ayat (1) dan (2) ditulis atau dicetak dengan menggunakan Bahasa Indoensia serta memuat paling sedikit keterangan mengenai :
a. Nama produk;
b. Daftar bahan yang digunakan;
c. Berat bersih atau isi bersih;
d. Nama dan alamat pihak yang memproduksi atau mengimpor;
e. Halal bagi yang dipersyaratkan
f. Tanggal dan kode produksi;
g. Tanggal, bulan dan tahun kadaluarsa
h. Nomor izin edar bagi Pangan Olahan; dan
i. Asal usul bahan pangan tertentu. 
(4) Keterangan pada label sebagaimana dimaksud pada ayat (3) ditulis dicetak atau ditampilkan secara tegas dan jelas sehingga mudah dimengerti oleh masyarakat.

Berdasarkan ketentuan pasal di atas maka diketahui bahwa label halal merupakan salah satu informasi yang dicantumkan pada produksi makanan oleh produsen untuk mengetahui apakah produk yang dihasilkannya benar kehalalannya atau keharamannya. Aturan umum yang sudah berlaku mengenai pencantuman label halal pada produk makanan haruslah melalui pemeriksaan dan sertifikasi halal terlebih dahulu oleh pihak yang berwenang agar diketahui kehalalan komposisi dan asal usul serta cara memproduksi makanan yang di produksinya. Selain sertifikat halal, produsen juga menggunakan label halal.

Sertifikasi Halal merupakan suatu kewajiban yang diberikan oleh lembaga BPOM dan BPJPH yang saat ini bekerjasama dengan LPPOM MUI. Lembaga tersebut menegaskan bahwa produk pangan yang halal harus sesuai dengan ketentuan standar yang telah ditetapkan. Sertifikat Halal ini dijadikan sebagai syarat untuk mendapatkan izin pencantuman label halal pada suatu kemasan produk dari pemerintah. Pengadaan Sertifikat Halal pada produk makanan bertujuan untuk memberi kepastian status halal suatu produk, sehingga dapat menenangkan konsumen.

Namun, jika melihat fakta yang ada dilapangan maka masih banyak produk berkemasan yang beredar di pasaran tidak mencantumkan label halal pada kemasannya, ataupun memasang logo halal palsu pada kemasannya. Hal-hal tersebut dinilai termasuk ke dalam hal pelanggaran atau perbuatan yang dilarang bagi pelaku usaha. Atas pelanggaran tersebut maka ada beberapa sanksi yang telah diatur di dalam beberapa peraturan perundangundangan yang akan diberikan bagi pelaku usaha, yakni berupa sanksi pidana maupun sanksi administratif.

Berdasarkan latar belakang di atas, maka yang menjadi perumusan masalah dalam penelitian ini adalah :

1. Bagaimanakah bentuk sanksi yang diterapkan oleh BBPOM di Padang dan LPPOM MUI Provinsi Sumatera Barat terhadap pelaku usaha yang mengedarkan produk pangan tanpa label halal pada kemasan di Kota Padang?.

2. Bagaimanakah penerapan sanksi yang telah dilakukan oleh BPPOM di Padang dan LPPOM MUI Provinsi Sumatera Barat terhadap pelaku usaha yang mengedarkan produk pangan tanpa label halal pada kemasan di Kota Padang?

\section{METODE PENELITIAN}

Berdasarkan pada masalah yang telah diuraikan diatas, maka Spesifikasi penelitian ini bersifat deskriptif analitis yaitu penelitian yang dilakukan untuk menggambarkan dan menguraikan objek penelitian atau masalah yang diteliti berupa kata-kata tertulis ataupun lisan dan perilaku orang-orang yang diamati. ${ }^{2}$ Penelitian deskriptif analitis ini diharapkan mampu memecahkan masalah dengan cara memaparkan keadaan obyek penelitian yang sedang diteliti apa adanya berdasarkan fakta-fakta yang diperoleh pada saat penelitian

\footnotetext{
${ }^{2}$ Soerjono Soekanto, Pengantar Penelitian Hukum, Universitas Indonesia (UI-Press), Jakarta, 1984, hlm. 51
} 
dilakukan sehingga dengan metode ini akan dapat diperoleh data yang lebih tuntas, pasti, dan memberikan gambaran secara mendalam dari suatu gejala sosial tertentu. ${ }^{3}$

Proses analisis data dalam penelitian ini adalah analisis yuridis kualitatif dengan penguraian secara deskriptif. Penentuan metode analisis seperti ini dilandasi oleh suatu pemikiran bahwa penelitian ini tidak hanya bermaksud menggambarkan (mendiskripsikan) data/objek penelitian sebagaimana apa adanya, melainkan juga bertujuan untuk memberikan argumentasi tentang Penerapan Sanksi Bagi Pelaku Usaha Yang Mengedarkan Produk Pangan Tanpa Label Halal Pada Kemasan di Kota Padang.

\section{PEMBAHASAN}

\section{Bentuk Sanksi Yang Diberikan Oleh BBPOM di Padang Dan LPPOM MUI Provinsi Sumatera Barat Terhadap Pelaku Usaha Yang Mengedarkan Produk Pangan Tanpa Label Halal Pada Kemasan di Kota Padang}

Negara Indonesia dalam menjamin setiap pemeluk agama untuk beribadah dan menjalankan agamanya, Negara berkewajiban memberikan perlindungan dan jaminan tentang kehalalan produk yang dikonsumsi dan digunakan masyarakat. Jaminan mengenai produk halal hendaknya dilakukan dengan asas perlindungan, keadilan, kepastian hukum, akuntabilitas dan transparansi, efektifitas dan efisien serta profesionalisme. Oleh karena itu jaminan penyelenggaraan produk halal bertujuan memberikan kenyamanan, keamanan, keselamatan dan kepastian ketersediaan produk halal bagi masyarakat dalam mengkonsumsi dan menggunakan produk, serta meningkatkan nilai tambah bagi pelaku usaha untuk memproduksi dan menjual produk halal.

Sertifikat halal serta label halal menjadi sangat penting artinya bagi konsumen muslim karena menyangkut prinsip keagamaan dan hak konsumen. Sementara terdapat fakta bahwa belum semua produk makanan bersertifikat halal maupun berlabel halal. Dengan demikian, upaya untuk memberikan perlindungan yang memadai terhadap kepentingan konsumen merupakan suatu hal yang penting dan mendesak untuk segera dicari solusinya dan perlu dibuat suatu aturan sanksi yang menjerat bagi pelaku usahanya.

Permasalahan ini muncul karena konsumen Indonesia semakin kritis dan membutuhkan kepastian tentang produk pangan yang dikonsumsinya baik dari sisi legalitas dan kualitas yang baik dan halal. Apalagi dengan terbukanya perdagangan bebas ASEAN melalui MEA (Masyarat Ekonomi Asean), produk-produk olahan pangan kemasan dari Negara lain akan beredar dengan leluasa di Indonesia.

Pada dasarnya keberadaan jaminan produk pangan halal berangkat dari informasi yang benar, jelas, dan lengkap baik secara kuantitatif maupun kualitas dari produk pangan yang mereka konsumsi. Pencantuman label halal sebagai konsekuensi sebuah produk yang bersertifikat halal akan mengembalikan hak-hak konsumen untuk menyelksi dan mengkonsumsi jenis makanan yang mereka hendak konsumsi.

Pencantuman label harus terbuka dan jelas terlihat, sehingga menunjukkan adanya itikad baik dari pelaku usaha untuk mengembalikan hak-hak konsumen. Karena selain untuk menjamin aspek kesheatan, juga bahkan yang sangat penting adalah sebagai bentuk pemberian jaminan perlindungan dan keupasan batiniah masyarakat.

\footnotetext{
${ }^{3} I b i d$.
} 
Pelaku usaha yang melakukan pelanggaran terkait labelisasi halal pada produk kemasan yang diproduksinya akan dikenai sanksi sebagai akibat hukum dari pelanggaran yang telah dilanggarnya. Pemberian sanksi terhadap pelanggaran pelaku usaha ini sangat penting dilakukan. Oleh karena itu sanksi merupakan hal yang sangat penting mengingat adanya pelaku usaha yang melanggar aturan mengenai label halal pada produk pangan yang diproduksi olehnya.

Untuk itu konsumen dihimbau agar meneliti dan menilai produk yang akan dikonsumsinya secara detail dan seksama. Sebagai konsumen khususnya konsumen muslim, kesalahan atau kekeliruan dalam memilih suatu produk yang dikonsumsinya dapat berujung pada kerugian lahir dan bathin. Secara lahir produk yang mengandung bahan berbahaya akan berdampak bagi eksehatan. Sedangkan secara bathin, mengkonsumsi produk yang tidak halal akan berdosa.

Berdasarkan hal diatas maka konsumen sangat perlu memahami informasi tentang produk yang akan dikonsumsinya. Sehingga keputusan untuk mengkonsumsi produk tertentu tidak semata-mata karena tergiur dengan kemasan yang menarik, iklan yang bombastis atau harga yang murah. Secara psikologis, setiap orang akan memilih segala sesuatu yang bersifat praktis, ekonomis dan hasil yang maksimal. Sikap tersebut tidak boleh dibiarkan tanpa adanya suatu upaya yang seharusnya dilakukan dan dipikirkan akibat yang akan ditimbulkan.

Terkait dengan pelanggaran pada label atas produk pangan yang dihasilkan oleh para pelaku usaha, maka terdapat beberapa sanksi sebagaimana yang telah diatur di dalam beberapa peraturan perundang-undangan di Indonesia. Sanksi tersebut dapat berupa sanksi perdata, pidana maupun administratif.

Apabila terjadi pelanggaran terhadap label halal yang digunakan pada produk pangan, maka Badan Penyelenggara Jaminan Produk Halal (BPJPH) dapat memberikan sanksi administratif selaku penerbit sertifikasi halal kepada pelaku usaha yang berupa peringatan tertulis, denda administratif atau pencabutan sertifikat halal. Sedangkan apabila konsumen merasa dirugikan akibat adanya pelanggaran atau pemalsuan terhadap label halal, maka konsumen dapat menuntut ganti rugi kepada pelaku usaha.

Terkait dengan pelaku usaha yang mencantumkan label halal tanpa sertifikasi halal, maka alur pemberian sanksi oleh LPPOM MUI yakni pelaku usaha akan diberikan peringatan secara tertulis, kemudian pelaku usaha dilarang untuk mengedarkan sementara waktu dan perintah untuk menarik produk pangan dari peredaran, pemusnahan pangan jika terbukti membahayakan kesehatan jiwa dan manusia, jika memang terbukti membahayakan maka produksi akan diberhentikan untuk sementara waktu, sanksi juga dapat berupa denda Rp. 50.000 .000 (lima puluh juta rupiah) dan pencabutan izin produksi atau izin usaha.

\section{Penerapan Sanksi Yang Dilakukan Oleh BPPOM di Padang dan LPPOM MUI Provinsi Sumatera Barat Terhadap Pelaku Usaha Yang Mengedarkan Produk Pangan Tanpa Label Halal Pada Kemasan di Kota Padang}

Keabsahan produk makanan dan/atau labelisasi halal sangatlah penting untuk menentramkan umat Islam Indonesia pada khususnya dalam memilih makanan dan minuman, karena dengan demikian umat muslim dapat dengan mudah untuk memilih dan mengetahui mana produk yang boleh dan mana produk yang tidak boleh dikonsumsi sesuai dengan ajaran agama Islam. Masalah ini menjadi penting untuk diperhatikan, karena untuk sekarang ini 
tidak akan bisa dengan mudah untuk memilah-milah dan membedakan mana yang haram dan mana yang halal. Ini berbeda dengan puluhan tahun yang lalu, dimana tanpa mengalami kesukaran yang berarti kita bisa membedakannya.

Kehalalan suatu produk menjadi kebutuhan yang wajib bagi umat muslim, baik itu makanan, obat-obatan maupun barang-barang konsumsi lainnya. Seiring besarnya kuantitas umat muslim di Indonesia. Konsumen Muslim di seluruh dunia telah membentuk segmen pasar yang potensial dikarenakan pola khusus mereka dalam mengkonsumsi suatu produk. Pola konsumsi ini diatur dalam ajaran Islam yang disebut dengan Syariat.

Dalam ajaran syariat, tidak diperkenankan bagi kaum muslim untuk mengkonsumsi produk-produk tertentu karena substansi yang dikandungnya atau proses yang menyertainya tidak sesuai dengan ajaran syariat tersebut. Dengan adanya aturan yang tegas ini maka para pemasar memiliki sekaligus barrier dan kesempatan untuk mengincar pasar khususnya kaum Muslimin.

Kejujuran produsen, kewaspadaan konsumen, serta regulasi Negara, merupakan kesatuan integral penegakan hukum mengenai produk halal. Salah satu masalah produk halal adalah mengenai sertifikasi halal dan pencantuman label halal pada kemasan produk yang bertujuan melindungi masyarakat dari produk haram dan membahayakan kesehatan. Akan tetapi kerapkali terjadi silang kepentingan dalam implementasinya, terutama antara produsen dan konsumen. Karena kejadian inilah LPPOM MUI serta BPPOM memiliki perhatian serius berikut tindakannya.

Produk-produk yang mendapat pertimbangan utama dalam proses pemilihannya berdasarkan ketentuan syariat yang menjadi tolak ukur untuk konsumen muslim adalah produk-produk makanan dan minuman. Ketidakinginan masyarakat muslim untuk mengkonsumsi produk-produk haram akan meningkatkan keterlibatan yang lebih tinggi dalam proses pemilihan produk. Proses pemilihannya sendiri akan menjadikan kehalalan sebagai parameter utamanya. Ketentuan ini membuat keterbatasan pada produk-produk makanan untuk memasuki pasar umat Muslim.

Selama ini, konsumen memerlukan kepastian hukum terhadap suatu produk apakah berlabel halal/haram terhadap seluruh pangan yang dikonsumsi, sehingga muncul adanya kecenderungan yang kuat bahwa konsumen muslim amat selektif dalam memilih produk pangan yang halal. Hal ini dapat berakibat pada pangan yang tidak berlabel halal mulai ditinggalkan konsumen, dan sebaliknya pangan yang berlabel halal mulai dicari konsumen.

Tujuan pemberian label pada pangan yang berkemasan adalah agar masyarakat yang membeli dan/atau mengkonsumsi pangan memperoleh informasi yang benar dan jelas tentang setiap produk pangan yang dikemas, baik menyangkut asal, kemasan, mutu, kandungan gizi maupun keterangan lain yang diperlukan sebelum memutuskan akan membeli dan/atau mengkonsumsi pangan tersebut. Ketentuan ini berlaku bagi pangan yang telah melalui proses pengemasan akhir dan siap untuk diperdagangkan, tetapi tidak berlaku bagi perdagangan pangan yang dibungkus dihadapan pembeli.

Salah satu bukti akan kehalalan produk tersebut aman untuk dikonsumsi adalah dengan pemasangan label halal pada produk pangan dalam kemasan tersebut, sehingga dengan adanya label halal tersebut dapat memberikan perlindungan terhadap konsumen Muslim sehingga konsumen Muslim merasa aman dalam mengkonsumsi produk kemasan 
yang mereka gunakan tersebut. Demikian halnya bagi konsumen non Muslim juga akan merasa aman dalam mengkonsumsi produk makanan dalam kemasan tersebut.

Terkait dengan proses kehalalan terhadap suatu produk pangan, maka BBPOM mempunyai persyaratan untuk pencantuman logo halal pada kemasan produk, yang terdiri dari :

a) Sertifikat Halal dari MUI yang masih berlaku dan sesuai dengan produk yang telah diajukan;

b) Pemenuhan Cara Produksi Pangan Olahan yang Baik (CPPOB) dibuktikan dengan hasil pemeriksaan sarana produksi terakhir dengan ketentuan sebagai berikut :

1) Apabila rating penilaian CPPOB adalah A (Baik Sekali) maka hasil pemeriksaan berlaku selama 2 (dua) tahun dan setelah itu harus dilakukan audit verifikasi kembali.

2) Apabila rating penilaian CPPOB adalah B (Baik), maka hasil pemeriksaan berlaku selama 1 (satu) tahun dan setelah itu harus dilakukan audit verifikasi kembali.

Jika dikaitkan dengan perlindungan konsumen khususnya bagi umat yang beragama Muslim dari produk pangan yang dalam kemasan agar terjamin kehalalannya maka dalam ketentuan Pasal 8 huruf h Undang-undang Nomor 8 Tahun 1999 tentang Perlindungan Konsumen, maka ditentukan bahwa pelaku usaha dilarang memproduksi dan/atau memperdagangkan barang dan/atau jasa yang tidak mengikuti ketentuan berproduksi secara halal, sebagaimana pernyataan "halal" yang dicantumkan dalam label.

Dengan adanya label halal yang tercantum pada kemasan pangan tersebut maka seharusnya konsumen Muslim sudah mendapatkan perlindungan bahwa label halal tersebut sudah sesuai dengan aturan yang ada, sehingga tercapainya hak dari konsumen yaitu berhak mendapatkan informasi yang benar, jelas, dan jujur mengenai kondisi dan jaminan barang dan/atau jasa. Sebagai lembaga pemerintah menyatakan bahwa tidak mudah untuk menentukan bahwa produk yang berada didalam kemasan tersebut halal atau haram, karena diperlukan pengetahuan yang khusus serta harus menggunakan peralatan yang canggih untuk meneliti bahan-bahan apa saja yang digunakan dalam produk pangan tersebut.

Badan POM merupakan lembaga yang berwenang melakukan pengawasan Obat dan Makanan. BPOM telah melakukan berbagai upaya untuk mengurangi kejahatan kemanusiaan terhadap obat dan makanan, diantaranya mengawasi sarana produksi dan distribusi Obat dan Makanan, melakukan pembinaan sarana yang melanggar aturan, berkoordinasi dengan aparat penegak hukum, pemerintah daerah, dan lintas sektor lainnya. Namun hal tersebut masih belum cukup mengurangi kejahatan di bidang Obat dan Makanan.

Jika melihat hasil temuan atas pengawasan yang telah dilakukan oleh BPPOM di Padang, maka dalam hal penerapan sanksi bagi pelaku usaha yang mengedarkan produknya khususnya tanpa label halal pada kemasan yang ada di Kota Padang adalah sanksi yang diberlakukan bagi pelaku usaha yang melakukan pelanggaran terkait proses pelabelan hanya berupa sanksi administratif yang berupa diberikannya teguran tertulis.

Di Kota Padang sendiri, menurut Ibu arma berdasarkan hasil wawancara penerapan sanksi administratif terhadap pelaku usaha yang memproduksi pangan berkemasan tanpa label halal belum dilakukan secara masif. Hal ini dikarenakan terkait proses penerbitan dan pencantuman label halal ada pada LPPOM MUI, dari pihak BPPOM hanya terkait dalam hal keseluruhan informasi yang ada pada kemasan pangan tersebut terutama sekali dalam hal izin 
edar. Dimana jika pelaku usaha tidak mempunyai izin edar maka sanksi administratif yang akan diberikan yakni berupa pencabutan izin dan penarikan produk pangan dari pasaran. ${ }^{4}$ Namun, untuk khususnya label halal dari pihak BPPOM hanya memberikan teguran tertulis, hal tersebut dikarenakan kewenangan selanjutnya dalam proses pencantuman label halal ada pada BPJPH yang bekerjasama dengan LPPOM MUI.

Seiring dengan perkembangan teknologi dan informasi yang berkembang di masyarakat, terdapat tantangan besar yang dihadapi oleh MUI dan LPPOM MUI dalam melaksanakan kewenangannya. Salah satunya yaitu dengan telah disahkannya Undangundang Nomor 33 Tahun 2014 tentang Jaminan Produk Halal. Dengan hadirnya UU JPH ini memang semakin menguatkan payung hukum dalam melindungi masyarakat agar mengkonsumsi barang halal. Tetapi hingga saat ini masih terdapat beberapa kontroversi terkait beberapa pasal yang terdapat dalam UU JPH tersebut terutama dalam hal kewenangan LPPOM MUI sebagai lembaga sertifikasi halal.

Dalam menjalankan fungsinya, LPPOM MUI melakukan pengkajian dan pemeriksaaan terhadap produk yang akan disertifikasi halal. Jika telah terdapat kejelasan maka hasil pemeriksaan tersebut akan dibawa ke Komisi Fatwa MUI untuk dibahas ditinjau dari syariat Islamnya. Jika telah menghasilkan suatu ketetapan barulah dibentuk sertifikat halal oleh MUI.

Pelaku usaha yang telah memperoleh sertifikat halal wajib mencantumkan label halal di kemasannya terhadap produk yang telah mendapatkan sertifikat halal, menjaga kehalalan produk yang telah memperoleh sertifikat halal, memisahkan lokasi, tempat dan penyembelihan, alat pengolahan, penyimpanan, pengemasan, pendistribusian, penjualan dan penyajian anatar Produk Halal dan Tidak Halal, memperbaharui sertifikat halal jika masa berlaku sertifikat halal berakhir, melaporkan perubahan komposisi bahan kepada BPJPH.

Pengawasan adalah salah satu faktor yang memberi perlindungan kepada konsumen atas peredaran barang dan/atau jasa di pasaran. Pengawasan pada jaringan produk halal yang dilakukan Badan Penyelenggara Jaminan Produk Halal (selanjutnya disebut BPJPH) adalah terhadap :

1. Lembaga Pemeriksa Halal;

2. Masa berlaku Sertifikat Halal;

3. Kehahalan Produk;

4. Pencantuman Label Halal:

5. Pencantuman Keterangan Tidak Halal;

6. Pemisahan lokasi, tempat dan alat penyembelihan, pengolahan, penyi,panan, pengemasan, pendistribusian, penjualan, serta penyajian antara Produk Halal dan Tidak Halal;

7. Keberadaan Penyelia Halal; dan/atau

8. Kegiatan lain yang berkaitan dengan Jaminan Produk Halal.

Menurut Pasal 53 Undang-undang Nomor 33 Tahun 2014 tentang Jaminan Produk Halal, dalam melakukan pengawasan peran masyarakat dalam membentuk jaminan produk halal juga sangat dibutuhkan. Hal yang dapat dilakukannya yakni dengan mengawasi produk

${ }^{4}$ Hasil wawancara dengan Ibu Armawati Anwar, selaku Koordinator Substansi Pemeriksaan BBPOM di Padang, pada hari Selasa tanggal 23 Maret 2021 
dan produk halal yang beredar di pasaran dapat berbentuk pengaduan atau pelaporan ke BPJPH. Berdasarkan bunyi ketentuan pasal tersebut maka penulis meilhat bahwa pengawasan dapat dilakukan dalam mengawasi produk-produk makanan yang tidak berlabel halal oleh pemerintah maupun oleh Lembaga Perlindungan Konsumen Swadaya Masyarakat dan masyarakat sendiri.

Menurut Bapak Syaifullah sendiri, sebenarnya sudah sering dilakukan sosialisasi, memberikan edukasi khusus dan melakukan penyidikan terhadap produk yang beredar ketika terjadi pelanggaran dengan instansi terkait yakni dengan Dinas Perdagangan dan Perindustrian Provinsi Sumatera Barat. Hal ini dilakukan agar para produsen dapat berproduksi sesuai dengan ketentuan yang ada diundang-undang, apalagi terkait dengan pencantuman label halal yang mana sangat dibutuhkan bagi masyarakat Sumatera Barat khususnya Kota Padang sendiri yang mayoritas beragama Islam. Namun, upaya tersebut masih banyak tidak diindahkan oleh para pelaku usaha karena label halal tersebut masih bersifat sukarela bukan merupakan kewajiban bagi pelaku usaha. Oleh karena itu, masih ada terdapat produk berkemasan yang tidak berlabel halal beredar di masyarakat. ${ }^{5}$

Jadi, dapat disimpulkan oleh penulis bahwa untuk pencantuman label halal yang sudah memiliki sertifikasi halal BPJPH, maka pelaku usaha harus melakukan pencantuman label halal ke BPJPH. Sehingga secara sederhana dapat dikatakan bahwa BPJPH mengeluarkan surat/izin keamanan produk (thoyyiban), sedangkan MUI menetapkan surat/jaminan kehalalan produk, sehingga dapat dipastikan produk tersebut merupakan produk yang aman dan sehat untuk dikonsumsi masyarakat.

Adapun upaya pemerintah dalam mengetahui status kehalalan suatu produk kemasan yaitu dengan tahap-tahap sebagai berikut :

1. Dilihat pada kemasan produk tersebut apakah tercantum nomor MD (Makanan Dalam negeri), SP (Sertifikat Penyuluhan) atau ML (Makanan Luar Negeri). Nomor MD dan ML dikeluarkan oleh BPOM, SP dikeluarkan oleh Dinas Kesehatan. Keterangan tentang peraturan pencantuman Nomor MD/SP/ML harus sesuai dengan Peraturan Menteri Kesehatan RI No. 382 Tahun 1989 tentang Pendaftaran Makanan.

2. Selanjutnya perhatikan apakah sudah ada logo halalnya. Apabila sudah ada, maka produk tersebut sudah dilakukan pemeriksaan kehalalan dan mendapat sertfiikat halal dari MUI sehingga sudah terjamin kehalalannya.

3. Untuk produk yang memiliki nomor MD/SP/ML, tetapi tidak ada label halal, bisa berarti produk tersebut belum diperiksa kehalalannya atau sudah mendapat sertifikasi halal tetapi masih dalam proses pengajuan pencantuman label halal di BPOM.

4. Apabila ditemukan pada label kemasan ada label halal, tetapi tidak ditemi nomor registrasi MD/SP/ML, maka produk tersebut tidak dijamin halal dan label halal yang tercantum adalah illegal dan diluar tanggung jawab BPOM.

Dalam hal penerapan sanksi yang diberikan bagi pelaku usaha yang melakukan pelanggaran di Kota Padang khususnya, maka makanan yang belum berlabel halal tidak akan

\footnotetext{
${ }^{5}$ Hasil wawancara dengan Bapak Syaifullah, selaku Direktur LPPOM MUI Provinsi Sumatera Barat, pada hari Kamis tanggal 25 Maret 2021
} 
ditarik oleh pemerintah, akan tetapi makanan yang akan ditarik dari peredaran adalah makanan yang sifatnya sudah membahayakan masyarakat banyak. LPPOM MUI maupun BPJPH tidak mempunyai kewenangan memberi sanksi kepada pelaku usaha yang tidak berlabel halal sebelum pelaku usaha memiliki sertifikat halal. Kecuali, jika pelaku usaha tersebut sudah mempunyai sertifikat halal maka baru dilakukan sanksi administratif yakni berupa pencabutan atas sertifikat halal yang dimilikinya. Jikalau belum sama sekali mempunyai sertifikat halal maka LPPOM MUI tidak bisa menindak-lanjutinya.

Menurut analisa penulis maka dapat disimpulkan bahwa jika terdapat suatu produk makanan yang tidak berlabel halal sama sekali, maka tidaklah akan ditarik oleh pemerintah yang berwenang kecuali produsen atau pelaku usaha tersebut sudah berurusan dengan lembaga terkait seperti memanipulasi sertifikat atau labelisasi halal, memiliki sertifikat halal tetapi memalsukan kehalalan produksinya, dan/atau konsumen telah merasa dirugikan barulah produsen tersebut ditindaklanjuti penangananannya oleh pihak yang berwenang. Apabila ada konsumen yang melapor dan merasa dirugikan atas informasi yang tidak benar upaya penindakan yang akan diberikan yakni berupa sanksi penjara. Hingga saat ini belum ada produsen yang mendapatkan sanksi penjara terkait dengan proses pemalsuan label halal ini.

Masih banyak beredarnya produk makanan yang tidak berlabel halal pada kemasan di pasaran hal ini dikarenakan masih rendahnya pengetahuan pelaku usaha terkait proses sertifikasi halal ini. Para pelaku usaha masih menganggap bahwa pencantuman label halal bukan suatu kewajiban dan masih bersifat sukarela, karena sebelum diberlakukannya UU JPH sifat dari sertifikasi halal ini masih bersifat voluntary (sukarela) bukan mandatory (kewajiban) kecuali bagi yang sudah mencantumkan label halal maka produsen harus bisa membuktikan kehalalannya. Saat ini setelah diberlakukannya UU JPH pada akhir tahun 2019 didalam undang-undang tersebut sifat dari sertifikasi halal kini sudah menjadi mandatory (kewajiban). Namun, faktanya saat ini masih banyak produk yang beredar di Kota Padang belum mencantumkan label halalnya.

Jadi, dapat disimpulkan bahwa jika perusahaan yang akan melakukan pelabelan halal secara legal maka haruslah melakukan sertifikasi terlebih dahulu. Hal ini untuk menghindari adanya pernyataan halal yang tidak sesuai. Suatu perusahaan yang membuat pernyataan halal secara tidak benar maka dapat dikenakan sanksi sesuai dengan beberapa peraturan perundang-undangan yang telah dijelaskan sebelumnya, sanksi itu dapat berupa sanksi administratif maupun sanksi pidana.

\section{PENUTUP}

Berdasarkan hasil penelitian, pembahasan dan analisis sebagaimana yang telah dipaparkan diatas, maka penulis dapat menarik kesimpulan sebagai berikut :

1. Bentuk sanksi yang diberikan oleh BBPOM di Padang dan LPPOM MUI Provinsi Sumatera Barat kepada para pelaku usaha yang melakukan pelanggaran terhadap pencantuman label halal pada kemasan ada diatur dalam beberapa peraturan perundangundangan, yakni : Undang-undang Nomor 18 Tahun 2012 tentang Pangan yang memberikan sanksi pidana, Undang-undang Nomor 33 Tahun 2014 tentang Jaminan Produk Halal yang memberikan sanksi administratif dan sanksi pidana, Undang-undang Nomnor 8 Tahun 1999 tentang Perlindungan Konsumen yang memberikan sanksi 
administratif dan sanksi pidana, Peraturan Pemerintah Nomor 69 Tahun 1999 tentang Label dan Iklan Pangan yang memberikan sanksi administratif, serta Peraturan Badan Pengawas Obat dan Makanan Nomor 31 Tahun 2018 tentang Label Pangan Olahan yang memberikan sanksi administratif

2. Penerapan sanksi bagi pelaku usaha di Kota Padang yang melakukan pelanggaran dinilai masih sangat ringan. Bagi pihak BBPOM sanksi yang diberikan terkait tidak adanya pencantuman label halal pada kemasan yakni berupa sanksi administratif yakni berupa teguran secara tertulis. Hal ini dikarenakan terkait proses penerbitan dan pencantuman label halal ada pada LPPOM MUI, dan dari pihak BPPOM hanya terkait dalam hal keseluruhan informasi yang ada pada kemasan pangan tersebut terutama sekali dalam hal izin edar. Dimana jika pelaku usaha tidak mempunyai izin edar maka sanksi administratif yang akan diberikan yakni berupa pencabutan izin dan penarikan produk pangan dari pasaran. Selanjutnya, LPPOM MUI maupun BPJPH tidak mempunyai kewenangan memberi sanksi kepada pelaku usaha yang tidak berlabel halal sebelum pelaku usaha memiliki sertifikat halal. Kecuali, jika pelaku usaha tersebut sudah mempunyai sertifikat halal maka baru dilakukan sanksi administratif yakni berupa pencabutan atas sertifikat halal yang dimilikinya. Jikalau belum sama sekali mempunyai sertifikat halal maka LPPOM MUI tidak bisa menindaklanjutinya.

\section{DAFTAR PUSTAKA}

\section{Buku Teks:}

Abdul Halim Barakatullah, Hukum Perlindungan Konsumen : Kajian Teoritis dan Perkembangan Pemikiran, Nusa Media, Bandung, 2008 , Hak-Hak Konsumen, Nusa Media, Bandung, 2010

Achmad Ali, Menguak Takbir Hukum (Suatu Kajian Filosofis dan Sosiologis), Penerbit Toko Gunung Agung, Jakarta, 2002

Ahmadi Miru dan Sutarman Ahmadi Miru dan Sutarman Yodo, Hukum Perlindungan Konsumen, Raja Grafindo, Jakarta, 2004

Ahmadi Miru, Prinsip-prinsip Perlindungan Hukum Bagi Konsumen Di Indonesia, cet. 2, PT. Raja Grafindo, Jakarta, 2013

Bambang Sunggono, Metode Penelitian Hukum, Alumni, Bandung, 2005

Barda Nawawi Arief, Kapita Selekta Hukum Pidana, PT. Citra Aditya Bakti, Bandung, 2003

Burhanuddin, Pemikiran Hukum Perlindungan Konsumen dan Sertifikasi Halal, Penerbit UIN Maliki Press, Malang, 2011

Hans Kelsen, Teori Umum tentang Hukum dan Negara, PT. Raja Grafindo Persada, Bandung, 2006

Indriyo Gitosudarmono, Manajemen Pemasaran Edisi Kedua, Yogyakarta, BPFE, 2014

Yusuf Qardhawi, Halal Haram dalam Islam, Era Intermedia, Surakarta, 2000

Zainuddin Ali, Metode Penelitian Hukum, Sinar Grafika, Jakarta, 2009

Zulham, Hukum Perlindungan Konsumen, Kencana Prenada Media Group, Jakarta, 2013

Asri, Perlindungan Hukum Bagi Konsumen Terhadap Produk Pangan Yang Tidak Bersertifikat Halal,Magister Ilmu Hukum Universitas Mataram, Jurnal IUS Vol. IV Nomor 2 Agustus 2016, Mataram, 2016

LPPOM MUI, Jurnal Halal Menentramkan Umat, No. 56/X/2005, Jakarta, 2005 
Zumroh Najiyah, Implementasi Kewajiban Pendaftaran Sertifikasi Halal Dalam Pasal 4 Undang-Undang Nomor 33 Tahun 2014 tentang Jaminan Produk Halal (Studi Pada LPPOM-MUI Jatim dan Industri Makanan dan Minuman Kota Pasuruan), Skripsi Fakultas Syariah, Universitas Islam Negeri Maulana Malik Ibrahim Malang, Malang, 2016

\section{Peraturan Perundang-undangan}

Kitab Undang-Undang Hukum Perdata (KUHPerdata)

Undang-undang Nomor 8 Tahun 1999 tentang Perlindungan Konsumen

Undang-undang Republik Indonesia Nomor 18 Tahun 2012 tentang Pangan

Undang-undang Nomor 33 Tahun 2014 tentang Jaminan Produk Halal

Undang-undang Nomor 23 Tahun 1992 tentang Kesehatan

Peraturan Pemerintah Nomor 69 Tahun 1999 tentang Label dan Iklan Pangan.

Peraturan Pemerintah Nomor 80 Tahun 2017 tentang Badan Pengawas Obat dan Makanan

Peraturan Menteri Kesehatan Republik Indonesia No. 76/Menkes/Per/III/78 tentang Label dan Periklanan Makanan

Peraturan Kepala Badan POM No. 12 Tahun 2016 tentang Pendaftaran Produk Pangan

Peraturan Badan Pengawas Obat dan Makanan Nomor 31 Tahun 2018 tentang Label Pangan

Olahan 